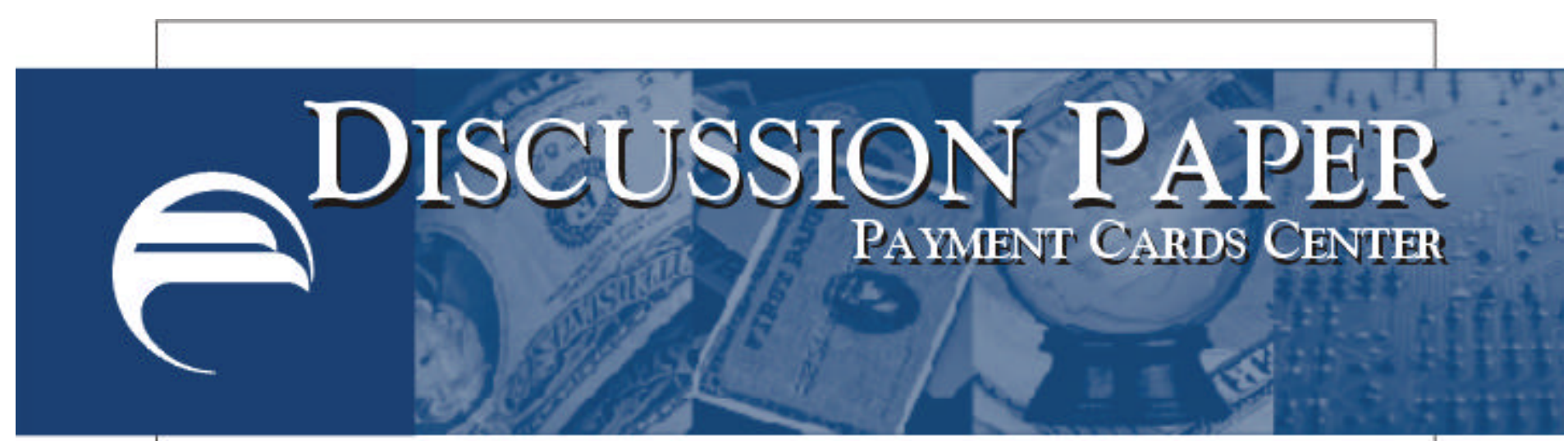

\title{
Credit Cards and Payment Efficiency ${ }^{1}$
}

\author{
Stan Sienkiewicz
}

August 2001

\begin{abstract}
Summary: On May 22, 2001, the Payment Cards Center of the Federal Reserve Bank of Philadelphia sponsored a workshop on the role of interchange fees in the credit card industry. The workshop discussion, led by Dr. David Humphrey of Florida State University, explored the framework behind interchange fees. ${ }^{2}$ It then focused on several open questions that have arisen within both the academic research and international regulatory communities about interchange's impact on payment system efficiency. The paper that follows is supplemented by additional research and provides background information on interchange, a transaction-level overview of the credit card system that results in the extraction of interchange, and a summary of Dr. Humphrey's comments.
\end{abstract}

${ }^{1}$ The views expressed here are not necessarily those of this Reserve Bank or of the Federal Reserve System.

${ }^{2}$ In September 2001, Dr. Humphrey was named a Payment Cards Center Visiting Fellow

\section{Federal Reserve Bank of Philadelphia}




\section{Background and History}

The payment mechanism that consumers use to purchase goods and services has changed dramatically over the last 100 years. At that time, almost all consumer transactions were in cash while business payments were in cash or checks. ${ }^{3}$ Proprietary charge cards came on the scene in the early 1900s, followed by "travel and entertainment" cards in 1950. For example, in the early 1920s, every three to six months, oil companies issued "courtesy" cards made of paper to car owners. These cards did not have a revolving credit feature. ${ }^{4}$ It wasn't until 1966, however, that the first generalpurpose credit card was introduced.

In a relatively short period, credit cards have become many consumers' preferred means of payment for travel, entertainment, retail purchases, and (in some cases) bill payment. In 1970, only 16 percent of households had a credit card, but by 1995 , approximately 65 percent had at least one credit card. ${ }^{5}$ Consumers' use of credit cards also increased as merchants' acceptance and the distribution of card-reader terminals increased. Credit cards are now accepted at over 4 million locations in the United States and over 14 million locations around the world. According to the most recently available figures, consumers used their credit cards to purchase over $\$ 1$ trillion of goods and services in $1999 .{ }^{6}$ Currently, credit cards account for almost 20 percent of all noncash transactions. (Evans and Schmalensee. 2000.)

\footnotetext{
${ }^{3}$ For a background on the changes in payment mechanisms, see William Baxter, "Bank Interchange of Transactional Paper: Legal and Economic Perspectives," Journal of Law \& Economics, Vol. 26, October 1983, pp. 541-88.

${ }^{4}$ Lewis Mandell, The Credit Card Industry: A History, Twayne Publishers, 1990.

${ }^{5}$ David Evans and Richard Schmalensee, Paying with Plastic: The Digital Revolution in Buying and Borrowing, The MIT Press, 2000.

${ }^{6}$ Card Industry Directory, Faulkner \& Grey, Inc., 2001.
} 
Before general-purpose credit cards (such as American Express, Visa, and MasterCard) were widely issued, merchants introduced proprietary charge cards as a means of creating customer loyalty and improving customer service. During the early part of the 1900s oil companies (courtesy cards) and department stores (charge-plates) issued their own proprietary cards. These store cards were accepted only at locations affiliated with the issuer of the cards in a limited geographic area. When a consumer traveled to another part of the country, the convenience associated with these cards was lost. In addition, prior to around 1930, only non-installment credit was offered. That is, card charges had to be paid in full each month. (Lewis Mandell. 1990.)

\section{General Purpose Credit Cards}

In 1950, the Diners Club issued the first "travel and entertainment" card, a general-purpose charge card that allowed consumers to make purchases using a payment card that was accepted by multiple merchants beyond their local geographic area. In 1958, American Express introduced its Green Card, another "travel and entertainment" card. These cards functioned in what is known as a "closed-loop" system, made up of the consumer, the merchant, and the issuer of the card. In this structure, the issuer both authorizes and handles all aspects of the transaction and settles directly with both the consumer and the merchant. That is, the card issuer, transaction processor, payor to the merchant, bill sender to the card user, and receiver of card-users' payments were effectively the same firm.

During the late 1950s and through the 1960s, several large banks developed "universal" card products that did not tie the consumer to a single merchant or product, thereby allowing the consumer to purchase goods and services in many places while 
providing a revolving credit feature. These early products were only marginally successful as "closed-loop" systems because merchants were reluctant to sign up with several issuing banks (with each bank serving only its own cardholders) and consumers saw little attraction in a payment vehicle restricted in terms of acceptance and geography (where multiple cards would have to be held to expand geographical coverage).

The general-purpose credit card was born in 1966, when the Bank of America established the BankAmerica Service Corporation that franchised the BankAmericard brand (later to be known as Visa) to banks nationwide. At about the same time, other banks formed the Interbank Card Association, later changed to MasterCard, to compete against BankAmericard. The new bank card associations were different from their predecessors in that an "open-loop" system was now created, requiring inter-bank cooperation and funds transfers.

As discussed earlier, Diners Club and American Express (and later the Discover Card) are "closed-loop" systems because a single firm captures and processes all of the transaction data. In the "closed-loop" system owners contract directly with both the cardholders and merchants, authorizing and settling all transactions. This differs from the "open-loop" systems of Visa and MasterCard that must share transaction data with thousands of members. When the issuing bank is different from the merchant's bank, the transaction between the two must be processed through a centralized system that authorizes and settles the transaction. The merchant's bank will send information to the issuing bank and the centralized system completes the transfer of exchange between the two parties. Interchange is the transfer of the credit transaction from the merchant through its bank to the credit card issuing bank and the debit from the issuer to the 
cardholder. This is also known as a four-party transaction, which includes the merchant, the acquiring bank, the issuing bank, and the consumer. ${ }^{7}$

\section{Flow of Information}

A typical flow of information when a consumer uses a credit card is illustrated below. The credit card is swiped through an electronic terminal at the merchant's location (1). The amount(s) of the transaction and cardholder details are routed to the merchant's bank (acquirer) (2). If the acquirer is also the issuer, the transaction can be authorized within the system, and authorization can be returned to the merchant (5). However, if the issuer is not the acquirer, the transaction is routed from the acquirer to the issuer through a switch facility provided by the credit card association (3). The issuer either authorizes or declines the transaction, and a message is sent to the acquirer (4) and then to the merchant (5). If authorization is given and the transaction is person-to-person, then the customer signs the voucher, the merchant compares the signature on the card with that on the voucher, and the transaction is complete (6).

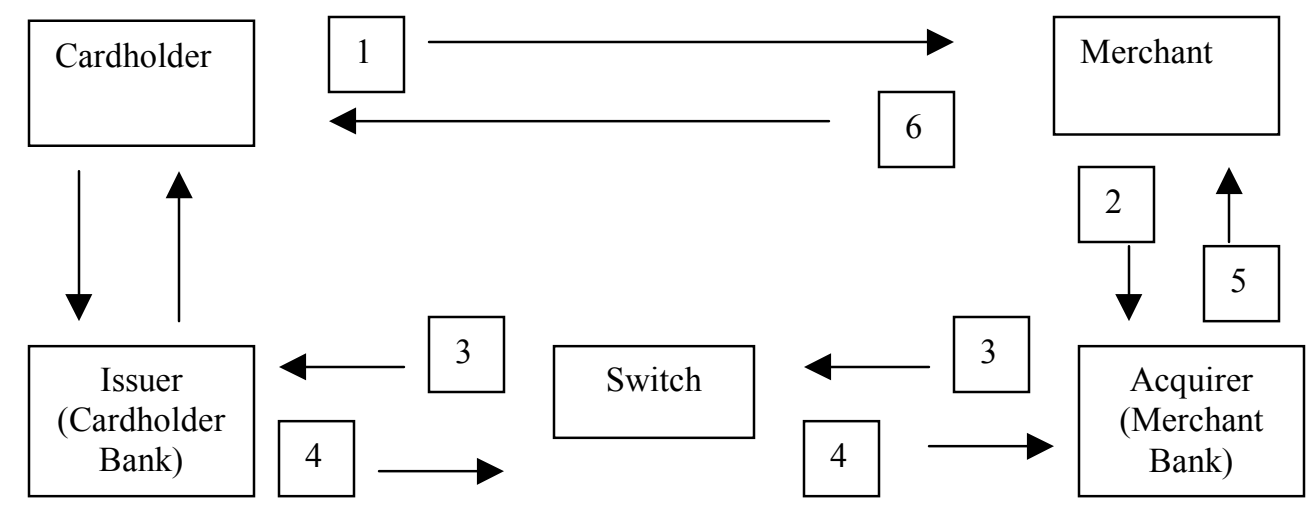

${ }^{7}$ While four parties are discussed in this simple representation of a credit card transaction, other participants, such as processors and independent sales organizations (ISOs), may be involved in the transaction. 
A key element of the "open-loop" system is that it requires the cooperation of all four parties for the transaction to be completed. If the parties acted independently, it is unlikely that the transaction would be successful. The actions necessary for the transaction to occur require the acceptance of the payment card by the merchant, the consumer, and both the acquiring and the issuing bank. In essence, these are jointly produced transactions requiring satisfaction of joint demand among the participating parties. There are strong positive feedback effects, also known as network effects. The value of the card to cardholders is higher if more merchants take the card and the value of the card to merchants is higher if more cardholders use the card.

Each issuer sets its own fees (annual fees, late fees, and finance charges) for the cards it issues and each acquirer contracts the fee (merchant discount) it charges the merchant for its services. To provide an incentive for banks to issue more cards and acquire more merchants and thus expand the network, bank card associations established the interchange fee used to allocate the costs and revenues between the issuer and acquirer. Put simply, the interchange fee is essentially a compensation vehicle. It helps ensure the cooperation and participation of the various parties in the system by balancing the incentives to increase the base of merchants accepting the card and the base of consumers using the card. This coordination, it is argued, has been essential to the success of the bank card associations and the growth of the industry.

Typically, merchant acquiring banks pay banks that issue Visa and MasterCard about 1.31 percent and 1.38 percent, respectively, of the value of the good or service being purchased. ${ }^{8}$ Recently, in response to more competitive offerings from the Discover

\footnotetext{
${ }^{8}$ Jason Fargo, The Quest for New Markets, Credit Card Management, March 1999.
} 
Card, the bank card associations have established lower interchange fees for purchases made at authorized grocery store chains.

While the merchant discounts are negotiated independently between merchants and acquiring banks, the interchange fee to compensate issuing banks is set by the bank card associations and is the same for all issuers. This arrangement recognizes the impracticality of separately negotiated interchange fees and serves to effectively link the joint demands among the various parties to the transaction. At the same time, this centrally established fee structure has had its share of critics and has been subject to legal challenges.

\section{Criticisms of Interchange}

One of the landmark legal cases attacking the interchange fee was that of NaBanco versus Visa in the early 1980s. NaBanco, a merchant acquirer, sued Visa, alleging that interchange fees charged by Visa member banks inhibited NaBanco's ability to compete in soliciting new merchant accounts with Visa members, who were often, both the acquiring and issuing bank. However, the court concluded "even if NaBanco had established that Visa had power in a relevant market and that 'the interchange fee' had substantial anticompetitive effects, Visa established that 'the interchange fee' is necessary to offer the Visa card, a pro-competitive benefit which offsets any anticompetitive effects." Generally, the court upheld the Visa network's imposition of interchange fees, finding that such fees are reasonably necessary to compensate the cardissuing bank for certain costs and is essential to the operation of the joint venture.

Others have argued that cash and check payment mechanisms subsidize credit card users. In a 1995 article, Dennis Carlton and Alan Frankel argued that "interchange 
fees allow credit customers to impose a tax on cash customers." If no interchange fee existed, banks would issue fewer credit cards and consumers would use credit cards more infrequently. ${ }^{10}$ They also argue that the bank card associations exercise market power through the collective actions of their members and are anti-competitive.

The question of the validity and necessity of interchange fees is not just being discussed in academic circles. The Reserve Bank of Australia recently conducted a study of interchange fees in the credit card industry in that country. ${ }^{11}$ The study concentrated on interchange fees and conditions of entry into the credit card industry. Concern centered on the economic efficiency of the networks and whether the best possible service at the lowest cost was being provided to the consumer. The Australian Reserve Bank study maintained that interchange fees are not easily recognizable by consumers and that interchange fees are built into the prices that merchants charge for goods and services to all consumers - not just those who use credit cards. Therefore, consumers who use cash, check, or debit cards are subsidizing credit card users.

The study concluded that credit card interchange fees are significantly above levels suggested by cost-based methodologies and thus are higher than necessary to maintain and promote the network. Since credit cards are more expensive for merchants to accept than are cash, debit cards, or even checks (either per transaction or for each

\footnotetext{
${ }^{9}$ NaBanco, 596. F. Supp. 1259-65.

${ }^{10}$ Dennis W. Carlton and Alan S. Frankel, "Symposium on Post Chicago Economics: The Antitrust Economics of Credit Card Networks," Antitrust Law Journal, Issue 2, Winter 1995, 63 ALJ 643.

11 "Debit and Credit Card Schemes in Australia: A Study of Interchange Fees and Access," Reserve Bank of Australia, October 2000.
} 
$\$ 100$ of sales), this suggests that a country is spending more on its payment system than it may need to. ${ }^{12}$

In October 2000, the European Commission launched formal proceedings against Visa International, alleging that interchange fees restrict competition. In August 2001, the Commission modified its earlier position, accepting the need for interchange fees, in exchange for Visa's agreement to reduce interchange fees and introduce objective evidence in setting the fee levels. ${ }^{13}$

\section{Professor David Humphrey's Discussion}

Professor Humphrey's own recent work has focused on the issue of interchange fees from the perspective of transaction costs and whether the costs involved with payment cards versus other payment vehicles (cash, check or debit) are charged to the appropriate party in the transaction and how this affects the overall cost efficiency of the payment system. He noted that the general response to criticism of an interchange fee essentially revolves around three issues. The first concerns the accurate measurement of the cost of acquiring merchants and servicing card users. The Australian study noted above suggested that the true costs were likely significantly lower than those associated with the interchange fee being used. The card industry replied that the study did not measure these costs correctly. This issue is an empirical question for which there is little public information available to decide conclusively one way or the other. The cost

\footnotetext{
${ }^{12}$ The cost of accepting different payment instruments at supermarkets is detailed in Food Marketing Institute, It All Adds Up-An Activity Based Cost Study of Retail Payments, Washington, D.C., 2001.

13 “EU Says Retailers Cannot Surcharge Visa Users," Reuters English News Service, August 10, 2001.
} 
analysis contained in the Australian study makes the best case it can, given the information at its disposal, which included some proprietary credit card cost information.

Bypassing this empirical question, it has also been argued that interchange fees derived from charges imposed on merchants are offset by benefits achieved by merchants, that is, greater merchant sales and lower loss rates with cards than with checks. In addition, card users benefit from having an expanded number of places to use their card. To cover credit card fees, however, merchants may have had to raise their prices (or accept lower profits) relative to what they otherwise might have done.

In Professor Humphrey's view these considerations raise two issues. First, card users are often given an incentive to use a credit card rather than cash, a debit card, or a check, since the merchant's price is the same even though a card user may receive frequent flyer miles (or some other inducement). Second, merchants may attract more customers and make more sales by accepting a credit card, so this extra cost could be offset by extra revenues.

He noted that in the beginning, consumers benefited from the expansion of credit card networks. But as more and more merchants have been added, the benefit of adding even more merchants becomes smaller. Most consumers find that their favorite merchants are already members of the network. In this respect, credit cards may be seen as a mature payment instrument in many countries (e.g., the U.S.). The cardholder base may similarly be seen as saturated: over 65 percent of U.S. households hold at least one general-purpose credit card. Consequently, costs incurred to expand further the merchant and card user base will not be nearly as productive as they were 10 or 20 years ago. 
As such, the original purpose of interchange has been largely accomplished, and in Professor Humphrey's view, the current environment suggests a strategy of shifting merchant-derived revenues from card usage away from additional merchant acquisition toward additional card use by offering incentives. The issue is that these incentives are only partly paid for by the card user. Since the card user did not earlier and does not now face the full cost of his/her decision to use a credit card, it is effectively "overused" relative to a situation where the full cost is assessed to the card user. But the full cost cannot generally be assessed, since contracts between merchants and credit card firms do not permit a surcharge for credit card use. Although it has been legal since the early 1990s to give a discount to customers who choose not to use a credit card, the effect is not the same. Merchants would have to raise their prices to be able to give a discount on some purchases and still have the same revenue as before. With a surcharge, prices do not have to rise, since the surcharge covers the higher cost of accepting a credit card, leaving the net revenues the same as before.

The final issue concerns the possibility that in accepting a credit card, merchants will make extra sales, and these sales will cover the extra cost involved. This argument has merit when few of a merchant's competitors are also members of a credit card network. Today, when almost all merchants accept credit cards, extra sales are unlikely to occur. What was once a way for merchants to offer customers something they could not easily obtain elsewhere now has become an expected service that no longer distinguishes one merchant from another. The expanded sales argument for merchants to accept credit cards is now essentially an argument for merchants to accept credit cards not to lose sales. 
Professor Humphrey's argument continues in suggesting that if merchants no longer have extra sales to cover the higher cost of accepting a credit card and they are not permitted to surcharge customers who use credit cards, then prices of goods and services will rise to cover this extra cost. With the introduction of frequent flyer miles and other inducements to use credit cards, the subsidy from users of cash and checks to credit card users is higher than it would otherwise be, since these inducements are at least partially paid from the interchange fees assessed when a credit card is used (beyond what might be recovered from annual fees or other charges). Only when everyone uses a credit card for all payments will the user pay the full cost of using a credit card. And for merchants, what once may have been a net benefit of accepting credit cards will become a net cost. Of course, the same thing occurred as checks replaced cash, since checks are somewhat more expensive to accept per $\$ 100$ of sales than is cash. However, since credit cards are more than just a little more expensive than checks, the net result for a country is a more expensive payment system.

Professor Humphrey closed by noting that consumers have many reasons, in addition to frequent flyer miles, to use credit cards-convenience, acceptability, and delayed billing come quickly to mind. The question is whether cardholders would continue to favor credit cards as much as they do today if they-rather than the merchants or the users of other payment instruments - paid the full cost involved. Which gets us back to the size of interchange and merchant fees.

In the end, interchange fees do provide incentives for the development of the network and card acceptance; however, whether these incentives are in the public's and 
payment system's best interest 30 years after the network is reaching maturity is the open question. 